\title{
ANALISIS BEBAN KERJA PADA CLEANING SERVICE DI PT. XYZ DENGAN METODE FULL TIME EQUIVALENT
}

\author{
Arnold Samuel Chan, Jessica Pratiwi, Lucy Sanjaya, Benedictus Rahardjo ${ }^{*}$ \\ Fakultas Teknologi Industri, Program Studi Teknik Industri, Universitas Kristen Petra \\ Jl. Siwalankerto 121-131, Surabaya 60236
}

(Received: September 21, 2017/ Accepted: January 25, 2018)

\begin{abstract}
Abstrak
PT. XYZ adalah perusahaan asing asal Jerman yang memproduksi circuit breaker (sebagai pelindung peralatan listrik). Penelitian ini bertujuan untuk mengetahui jumlah tenaga bagian kebersihan (cleaning service) yang optimal sebab melalui pengamatan dari beberapa manajer, petugas cleaning service seringkali menganggur. Jumlah tenaga cleaning service saat ini adalah 9 orang. Metode yang digunakan dalam penelitian ini adalah Full Time Equivalent (FTE). Metode FTE dilakukan dengan menghitung total waktu beban kerja pada seluruh lokasi di PT. XYZ dan jumlah jam kerja efektif. Total waktu beban kerja petugas cleaning service adalah 464.746,5 menit dan total jam kerja efektif selama setahun setelah diberikan allowance adalah 93.585 menit. Total nilai FTE tenaga cleaning service adalah 4,97 yang berarti jumlah tenaga yang dibutuhkan adalah 5 orang.
\end{abstract}

Kata Kunci: beban kerja; karyawan; Full Time Equivalent

\begin{abstract}
PT. XYZ is a foreign company based in German that manufactures circuit breaker (to protect an electrical devices). This research aims to find an optimum number of needed cleaning service's employees as the information from the manager at PT. XYZ said that the current cleaning service's employees are frequently idle. The current cleaning service's total employees are 9. The method used in this research was Full Time Equivalent (FTE). FTE was applied by counting the total time workload at the entire location of PT. XYZ and the total effective working hours. Total time workload of the cleaning service's employees are 464,746.5 minutes and the total effective working hours a year after adjusted with the allowance is 93,585 minutes. Total FTE value for cleaning service's employee is 4.97 which means only 5 employees needed.
\end{abstract}

Keywords: Workload; Employee; Full Time Equivalent

\section{PENDAHULUAN}

Sebuah perusahaan yang bergerak di bidang manufaktur memiliki dua sumber daya manusia yang cukup berperan penting, yaitu tenaga di lantai produksi dan tenaga sumber daya yang mendukung jalannya produksi. Kedua komponen tersebut perlu ada sebab keduanya berfungsi sebagai penggerak utama dalam perkembangan perusahaan. Berdasarkan kriteria ergonomi (Kamala et al., 2016) dijelaskan bahwa performa kinerja dari seorang pekerja dipengaruhi oleh beberapa faktor. Salah satu faktor tersebut adalah kondisi lingkungan kerja yang meliputi kebersihan area kerja. Kebersihan dari perusahaan dan area kerja merupakan tanggung jawab bagian staf cleaning service, baik itu yang

\footnotetext{
${ }^{*}$ Penulis Korespondensi.

e-mail: beni@petra.ac.id
}

berasal dari karyawan tetap perusahaan maupun pekerja outsource.

PT. XYZ merupakan perusahaan yang bergerak pada produksi sekring dalam skala besar. PT. XYZ awalnya mempekerjakan lima orang cleaning service dalam mendukung lingkungan kerja yang baik bagi operator produksi. Lima pekerja ini terdiri dari empat orang tenaga cleaning service dan satu orang yang berperan sebagai koordinator cleaning service. Akibat adanya penambahan gedung baru di sebelah gedung lama, berdasarkan rekomendasi dari koordinator cleaning service, ditambahkan lima orang pekerja untuk membantu divisi cleaning service dalam membersihkan area gedung tambahan.

Pada fakta di lapangan, pekerja cleaning service selain dapat menyelesaikan job description utamanya juga dapat mengerjakan pekerjaan lain yang bukan merupakan tugasnya. Pekerjaan lain yang dimaksud, yaitu mengecat ulang jalur di lantai produksi dan halaman, merekap inventori, dan membelikan 
makanan. Pekerjaan lain ini seharusnya dikerjakan oleh staf kantor, namun melihat bahwa pekerjaan membersihkan telah selesai dilakukan maka pekerjaan ini dibebankan pada pekerja cleaning service. Pekerjaan lain ini tidak ada dalam job description yang seharusnya dibebankan ke cleaning service, namun pekerja cleaning service mampu menyelesaikan tugas utamanya dan tambahan pekerjaan lain. Setelah dua tahun berjalan, manajer HRD PT. XYZ melihat bahwa jumlah pekerja cleaning service saat ini tidak proporsional bila dibandingkan dengan beban kerja cleaning service yang seharusnya dalam membersihkan gedung karena adanya pekerjaan lain yang mampu diselesaikan oleh cleaning service.

Manajemen sumber daya manusia menjadi hal yang penting dan berkaitan dengan permasalahan di PT. XYZ. Sumber daya manusia yang berlebihan dapat mengakibatkan proses bisnis tidak berjalan efektif serta pembengkakan biaya bagi perusahaan (Freivalds, 2012). Banyak bisnis yang melakukan downsizing untuk mengefektifkan jumlah pekerja dengan pekerjaan (job description).

Metode FTE (Full Time Equivalent) adalah sebuah unit satuan yang menunjukkan beban kerja seorang karyawan yang mana nilai beban kerja ini dapat dijadikan sebagai patokan perbandingan dalam berbagai macam konteks (Megbo et al., 2015). Nilai FTE memberikan perspektif yang lebih baik mengenai jumlah tenaga kerja yang dibutuhkan berdasarkan beban kerja atau tugas yang harus dikerjakan karyawan.

Oleh karena itu, dalam penelitian ini akan dilakukan perhitungan beban kerja dari cleaning service PT. XYZ yang digunakan untuk menentukan jumlah tenaga kerja cleaning service yang seharusnya diperlukan. Beban kerja yang sesuai dapat meningkatkan performa pekerja cleaning service dan juga dapat mengurangi biaya perusahaan yang dikeluarkan untuk bagian cleaning service.

\section{METODE PENELITIAN}

Penelitian di PT.XYZ dilakukan dengan cara wawancara dan observasi. Hasil wawancara dan observasi dikumpulkan sebagai data durasi lama cleaning service menyelesaikan sebuah aktivitas. Wawancara dilakukan kepada Kepala cleaning service.



Gambar 1. Alur Pengumpulan Data dan Perhitungan Indeks FTE Pekerja 
Metode FTE mengukur kemampuan atau kapasitas pekerja sehingga dapat digunakan dalam peramalan kebutuhan pekerja dalam suatu periode tertentu (Hasibuan, 2005). Metode ini digunakan apabila diperlukan adanya penambahan atau bahkan sebaliknya yaitu pengurangan dari jumlah pekerja yang sekarang dimiliki. Persamaan FTE dapat dilihat pada (1).

\section{FTE $=($ Total Waktu Beban Kerja $) /($ Jam Kerja Efektif)

Waktu beban kerja adalah waktu penyelesaian aktivitas setelah dikalikan frekuensi penyelesaiannya. Beban Kerja ini adalah tolak ukur yang dapat digunakan untuk menghitung berapa pekerja yang dibutuhkan (Kep. Men.PAN Nomor: KEP/75/M.PAN/7/ 2004). Waktu penyelesaian aktivitas yang dicatat adalah dalam satu hari pengamatan selama pekerja berada pada jam kerjanya (U.S. Small Business Administration, 2013). Sesuai dengan standar yang berlaku, satu hari kerja dapat dikonversikan menjadi delapan jam kerja. Waktu beban kerja dapat diperoleh dari (2).

Total waktu beban kerja diperoleh dengan menjumlahkan seluruh hasil perkalian durasi penyelesaian aktivitas dengan frekuensi pengerjaan aktivitas. Durasi penyelesaian aktivitas diperoleh dari lamanya pekerja cleaning service menyelesaikan sebuah aktivitas. Frekuensi adalah total berapa kali aktivitas tersebut dilakukan dalam setahun.

Total waktu beban kerja $=\Sigma($ Durasi penyelesaian aktivitas $x$ Frekuensi)

Total jam kerja efektif dapat diperoleh dari persamaan (3).

$$
\begin{aligned}
& \text { Jam Kerja Efektif }(\text { dalam } 1 \text { tahun })= \\
& \{(H-C-L) \times 8 \times 60\}
\end{aligned}
$$

di mana:

$\mathrm{H}=$ Total hari kerja yang ada dalam setahun

$\mathrm{C}=$ Total hari cuti yang diperbolehkan oleh perusahaan dalam setahun

$\mathrm{L}=$ Total hari libur perusahaan dan nasional yang ada dalam setahun

\section{HASIL DAN PEMBAHASAN}

\section{Data}

Data yang akan digunakan dalam penelitian ini adalah waktu penyelesaian tugas dari masingmasing job description dan frekuensi pemberlakuan tugas (job description). Data yang digunakan dikumpulkan mulai dari tanggal 22 Desember 2015 hingga 14 Februari 2016. Objek yang diamati adalah seluruh petugas cleaning service yang bekerja di PT. XYZ.

Perhitungan beban kerja dengan metode Full Time Equivalent yang dilakukan oleh Sugiono dan Palit, 2016, pada pekerjaan repetitif yaitu pencampuran material. Penelitian ini digunakan untuk membagi beban aktivitas yang dilakukan dalam pekerjaan pencampuran material secara adil untuk tiap pekerja. Penelitian ini dilakukan dengan mengumpulkan data observasi aktivitas yang dilakukan dalam pencampuran material dan waktu yang diperlukan. Waktu observasi tersebut kemudian digunakan untuk menghitung waktu baku tiap aktivitas. Beban setiap aktivitas dalam pekerjaan pencampuran material menggunakan index FTE, yaitu dari waktu baku aktivitas. Index FTE tiap orang dengan beban normal adalah dalam range 1,001,28. Index FTE tiap aktivitas kemudian disesuaikan dengan kapasitas pekerjanya.

Pekerjaan di divisi cleaning service PT. XYZ adalah pekerjaan non-repetitif yang memiliki range aktivitas yang luas dan bermacam-macam. Index FTE akan digunakan untuk menghitung pekerja yang dibutuhkan dalam melakukan segala job description yang ditugaskan. Penelitian ini akan menggunakan index FTE 1,00 sebagai kapasitas setiap orang dalam menerima beban kerja.

Jumlah cleaning service yang bekerja di PT. XYZ saat ini adalah delapan orang karyawan dan satu orang sebagai kepala cleaning service. Data dikumpulkan melalui hasil wawancara serta observasi lapangan. Berdasarkan keterangan yang diperoleh dari kepala cleaning service, Tabel 1 adalah pembagian kerja untuk setiap pekerja.

Area - area yang telah diketahui kemudian dispesifikkan lebih lanjut lagi. Data didetailkan menjadi list data ruangan yang ada pada area terebut. Hal ini dilakukan agar pengumpulan data waktu dapat lebih mudah diperoleh. Pengumpulan data waktu didapat dari data pengerjaan semua aktivitas pada setiap lantai yang ada. Total data waktu tersebut kemudian dirangkum untuk mempermudah perhitungan waktu beban kerja.

Data dalam Tabel 2 menunjukkan jumlah beban kerja dari masing-masing aktivitas yang dilakukan oleh petugas cleaning service pada beberapa ruangan di lantai 1 PT XYZ. Perhitungan dalam penelitian ini akan dilakukan untuk seluruh lokasi PT XYZ, yaitu pada lantai 1 , lantai 2 , produksi $5 \mathrm{~A}$, gudang 5 , gudang $5 \mathrm{~A}$, toilet, halaman, pantry, produksi dan gudang. Total waktu beban kerja pada masing-masing area ditunjukkan dalam Tabel 3. 
Tabel 1. Pembagian Tugas Cleaning Service PT. XYZ

\begin{tabular}{|c|c|c|c|c|c|c|c|c|}
\hline Jam & Pekerja 1 & Pekerja 2 & Pekerja 3 & Pekerja 4 & Pekerja 5 & Pekerja 6 & $\begin{array}{l}\text { Pekerja 7/ } \\
\text { Pekerja } 8 \\
\end{array}$ & Keterangan \\
\hline $\begin{array}{c}06.00- \\
07.00\end{array}$ & $\begin{array}{c}\text { Ruang } \\
\text { kerja \& } \\
\text { office atas }\end{array}$ & $\begin{array}{l}\text { Ruang } \\
\text { kerja \& } \\
\text { office } \\
\text { atas } \\
\end{array}$ & $\begin{array}{l}\text { Ruang } \\
\text { kerja \& } \\
\text { office } \\
\text { atas } \\
\end{array}$ & $\begin{array}{c}\text { Ruang } \\
\text { kerja \& } \\
\text { office } \\
\text { atas } \\
\end{array}$ & Halaman & \multirow{2}{*}{\multicolumn{2}{|c|}{$\begin{array}{c}\text { Pekerja } 7 \text { dan Pekerj } \\
8 \text { bergantian tiap } \\
\text { seminggu }\end{array}$}} & \multirow{2}{*}{$\begin{array}{c}\text { Ruang Kerja \& Office } \\
\text { Meliputi seluruh isi ruangan } \\
\text { harus bersih dari debu, tempat } \\
\text { sampah, dan kaca, dinding, } \\
\text { toilet }\end{array}$} \\
\hline $\begin{array}{c}07.00- \\
08.00\end{array}$ & $\begin{array}{c}\text { Ruang } \\
\text { kerja \& } \\
\text { office atas }\end{array}$ & Gudang & $\begin{array}{c}\text { Ruang } \\
\text { kerja \& } \\
\text { office } \\
\text { atas }\end{array}$ & Produksi & Toilet & & & \\
\hline $\begin{array}{c}08.00- \\
09.00 \\
\end{array}$ & Halaman & Produksi & Produksi & Produksi & Gudang & Gudang & Produksi & \multirow{2}{*}{$\begin{array}{c}\text { Ruang Gudang } \\
\text { Meliputi seluruh rak, lantai } \\
\text { dan ruang pimpinan sehingga } \\
\text { bersih dari sawang-sawang }\end{array}$} \\
\hline $\begin{array}{c}09.00- \\
10.00 \\
\end{array}$ & Produksi & Produksi & Gudang & Gudang & Produksi & Produksi & Gudang & \\
\hline $\begin{array}{l}10.00- \\
11.00 \\
\end{array}$ & Istirahat & Istirahat & Halaman & Produksi & Produksi & Produksi & Toilet & \multirow{2}{*}{$\begin{array}{c}\text { Ruang Produksi } \\
\text { Meliputi seluruh lantai dan } \\
\text { kaca dinding, toilet produksi } \\
\text { laki-laki dan toilet produksi } \\
\text { perempuan }\end{array}$} \\
\hline $\begin{array}{l}11.00- \\
12.00\end{array}$ & $\begin{array}{c}\text { Office atas } \\
\& \text { bawah }\end{array}$ & Halaman & Istirahat & Istirahat & Istirahat & Toilet & Gudang & \\
\hline $\begin{array}{l}12.00- \\
13.00\end{array}$ & Produksi & Produksi & Gudang & Toilet & Gudang & Istirahat & Istirahat & \multirow{3}{*}{$\begin{array}{c}\text { Halaman } \\
\text { Meliputi pintu masuk, } \\
\text { menyapu halaman, pos } \\
\text { satpam, kantin, termasuk } \\
\text { saluran got, menyiram bunga } \\
\text { dalam pot, membersihkan kaca } \\
\text { dinding luar, toilet, meja kursi, } \\
\text { dan musholla }\end{array}$} \\
\hline $\begin{array}{l}13.00- \\
14.00\end{array}$ & Produksi & Toilet & $\begin{array}{l}\text { Office } \\
\text { atas \& } \\
\text { bawah }\end{array}$ & Halaman & Produksi & Gudang & Gudang & \\
\hline $\begin{array}{l}14.00- \\
15.00\end{array}$ & Toilet & Gudang & Gudang & Produksi & Produksi & Produksi & Produksi & \\
\hline $\begin{array}{l}.00- \\
.00\end{array}$ & & & & & & & Toilet & \multirow{2}{*}{$\begin{array}{c}\text { Toilet } \\
\text { Membersihkan semua toilet, } \\
\text { produksi laki-laki, perempuan, } \\
\text { satpam, kantin, driver, toilet } \\
\text { atas dan bawah }\end{array}$} \\
\hline $\begin{array}{l}16.00- \\
17.00\end{array}$ & & & & & & & $\begin{array}{c}\text { Office atas } \\
\& \text { bawah }\end{array}$ & \\
\hline
\end{tabular}

Tabel 2. Data Durasi Penyelesaian Aktivitas

\begin{tabular}{|c|c|c|c|c|c|c|c|}
\hline Ruangan & Aktivitas & $\begin{array}{c}\text { Frekuensi dalam } \\
\text { Seminggu }\end{array}$ & & Irasi & $\begin{array}{c}\text { Banyak } \\
\text { Orang }\end{array}$ & $\begin{array}{l}\text { Beban } \\
\text { Kerja }\end{array}$ & Dalam Setahun \\
\hline \multirow{4}{*}{$\begin{array}{l}\text { Archive } \\
\text { Room }\end{array}$} & Menyapu & 2 bulan $1 \mathrm{x}$ & 10 & menit & 1 & 10 & 60 \\
\hline & Mengepel & 2 bulan $1 x$ & 10 & menit & 1 & 10 & 60 \\
\hline & Vacuum Rak & 2 bulan $1 x$ & 5 & menit & 1 & 5 & 30 \\
\hline & Mengelap & 2 bulan $1 x$ & 5 & menit & 1 & 5 & 30 \\
\hline \multirow{3}{*}{$\begin{array}{l}\text { Student } \\
\text { Room }\end{array}$} & Menyapu & 5 & 5 & menit & 1 & 25 & 1225 \\
\hline & $\begin{array}{l}\text { Mengepel \& } \\
\text { Memungut } \\
\text { Sampah }\end{array}$ & 5 & 4 & menit & 1 & 20 & 980 \\
\hline & Mengelap & 5 & 4 & menit & 1 & 20 & 980 \\
\hline \multirow{3}{*}{$\begin{array}{l}\text { General } \\
\text { Manager }\end{array}$} & Menyapu & 5 & 7 & menit & 1 & 35 & 1715 \\
\hline & $\begin{array}{l}\text { Mengepel \& } \\
\text { Memungut } \\
\text { Sampah }\end{array}$ & 5 & 6 & menit & 1 & 30 & 1470 \\
\hline & Mengelap & 5 & 4 & menit & 1 & 20 & 980 \\
\hline \multirow{3}{*}{$\begin{array}{l}\text { First Aid } \\
\text { Clinic }\end{array}$} & Menyapu & 5 & 7 & menit & 1 & 35 & 1715 \\
\hline & $\begin{array}{l}\text { Mengepel \& } \\
\text { Memungut } \\
\text { Sampah }\end{array}$ & 5 & 6 & menit & 1 & 30 & 1470 \\
\hline & Mengelap & 5 & 5 & menit & 1 & 25 & 1225 \\
\hline
\end{tabular}


Tabel 3. Total Waktu Beban Kerja pada Setiap Area di PT.XYZ

\begin{tabular}{lc}
\hline \multicolumn{1}{c}{ Area } & $\begin{array}{c}\text { Waktu Beban Kerja } \\
\text { (menit) }\end{array}$ \\
\hline Lantai 1 & $72.896,0$ \\
\hline Lantai 2 & $77.469,0$ \\
\hline Produksi 5 & $54.292,0$ \\
\hline Produksi 5A & $42.801,5$ \\
\hline Gudang 5 & $38.995,0$ \\
\hline Gudang 5A & $12.005,0$ \\
\hline Toilet & $27.685,0$ \\
\hline Halaman & $53.775,0$ \\
\hline Pantry & $67.228,0$ \\
\hline Produksi dan Gudang & $17.640,0$ \\
\hline Total Waktu Beban Kerja & $464.746,5$
\end{tabular}

\section{Perhitungan}

\section{Total Waktu Beban Kerja $=464.746,5$ menit}

Total waktu beban kerja diperoleh dengan menjumlahkan semua beban kerja masing-masing aktivitas. Total waktu beban kerja dalam setahun diperoleh 464.746,5 menit.

Jam kerja efektif adalah jumlah jam kerja formal dikurangi dengan waktu kerja yang hilang karena tidak bekerja (cuti).

Jam KerjaEfektif (dalam 1 tahun) $=(190) \times 8 \times 60+(42) \times 7,5 \times 60$ $=110.100$ menit

Perusahaan juga memberikan allowance kepada pekerja untuk melakukan keperluan pribadi dan aktivitas pelepas lelah. Nilai allowance yang diberikan PT. XYZ adalah sebesar $15 \%$ dari jam kerja yang ada.

Jam Kerja setelah Allowance = Jam kerja Efektif $x(1-$ Allowance $)=$ 110.100 menit $x(1-0,15)=93.585$ menit

Data yang diperlukan untuk menghitung Full Time Equivalent adalah total waktu beban kerja dan jam kerja efektif. Hal yang selanjutnya dilakukan adalah melakukan penghitungan Full Time Equivalent untuk mengetahui tenaga kerja yang dibutuhkan. Penghitungan Full Time Equivalent dapat menggunakan persamaan (1).

$F T E=\frac{464.746,5}{93.585}=4,97$

Hasil perhitungan ini menunjukkan bahwa jumlah pekerja cleaning service dengan job description sekarang yang diperlukan di PT. XYZ adalah sebanyak lima orang. Melihat jumlah pekerja cleaning service yang ada sekarang sebanyak sembilan orang, jumlah yang ada sekarang masih belum ideal. Apabila dilakukan pengurangan pekerja, pekerjaan-pekerjaan di luar job description yang selama ini dikerjakan cleaning service perlu dipertimbangkan. Pekerjaan seperti membantu maintenance, membantu bagian QC, dan pekerjaanpekerjaan yang ada ketika ada acara-acara tertentu dapat menambah beban kerja dari pekerja.

\section{KESIMPULAN}

Total beban kerja yang ada dari seluruh aktivitas yang dikerjakan oleh petugas cleaning service dapat diperoleh dengan menjumlah beban kerja masingmasing aktivitas. Beban kerja masing-masing aktivitas diperoleh dari hasil kali frekuensi perlakuan aktivitas dengan durasi yang diperlukan. Total beban kerja yang didapat adalah 464.746,5 menit. Jumlah pekerja cleaning service yang diperlukan dapat dihitung dengan menggunakan metode Full Time Equivalent. Metode ini memerlukan data total beban kerja yang ada dan jam kerja efektif dari pekerja. Total beban kerja yang diperoleh sebesar 464.746,5 menit dan jam kerja efektif yang diperoleh sebesar 93.585 menit. FTE yang diperoleh dari hasil bagi total beban kerja dengan jam kerja efektif adalah sebesar 4,97. FTE sebesar 4,97 menandakan pekerja ideal yang dibutuhkan dengan beban kerja yang diketahui adalah 5 orang.

Perhitungan waktu kerja dalam penelitian ini adalah hasil wawancara dan beberapa observasi saja karena keterbatasan waktu dan perijinan. Keakuratan waktu yang baik dapat diperoleh dengan mengaplikasikan ilmu Time Study. Tiap-tiap pekerjaan dapat diidentifikasi secara langsung dengan melakukan observasi dan pencatatan waktu pekerjaan. Waktu yang telah dicatat untuk tiap-tiap pekerjaan lalu dijadikan waktu normal dengan melihat performa dari pekerja tersebut. Waktu baku untuk masing-masing pekerjaan dapat diperoleh dengan mempertimbangkan kelonggaran kerja untuk masing-masing pekerjaan. Penghitungan waktu secara detil ini akan membantu keakuratan waktu masing-masing pekerjaan. 
Penelitian ini juga mengalami berbagai hambatan tak terduga. Hambatan-hambatan tersebut berupa seperti matinya listrik kantor, aktivitasaktivitas yang mengganggu pekerjaan misal membantu divisi lain untuk mengecat, melakukan rekapitulasi gudang dan lain-lain. Pengukuran dan observasi ketika ada aktivitas ini akan memengaruhi kinerja dan bagaimana pekerja lainnya melakukan pekerjaannya. Hal ini dapat menyebabkan ketidakakuratan data aktivitas yang dilakukan pekerja. Penelitian berikutnya harap mempertimbangkan faktor-faktor tidak terduga dan data diambil ketika keadaan normal.

\section{DAFTAR PUSTAKA}

Hasibuan, M. S. 2005. Manajemen Sumber Daya Manusia. Jakarta: PT Gramedia Pustaka Utama.

Sugiono, H. and Palit, H. C. 2016. Penentuan Jumlah Tenaga Kerja Pada Departemen MPC: A Case Study. Jurnal Titra, Vol. 4, No. 2, pp. 223-228.

Jordan USAID. 2015. Workload-Based Projections of Staffing Needs. USA: United States Agency for International Development.
Kementrian Pendayagunaan Aparatur Negara Republik Indonesia. 2004. Pedoman Perhitungan Kebutuhan Pegawai Berdasarkan Beban Kerja dalam Rangka Penyusunan Formasi Pegawai Sipil (Kep.Men.PAN Nomor: KEP/75/M.PAN/ 7/-2004). Jakarta: Kementrian Pendayagunaan Aparatur Negara.

U.S. Small Business Administration. 2013. Retrieved from U.S. Small Business Administration: https://www.sba.gov/Calculating_FTEs_for_Emplo yer_Shared_Responsibility.

Kamala, V., Malliga, P. and Priyanka, G. M.. 2016. Criteria Based Ergonomic Assessment in a Manufacturing Industry. IEEE International Conference on Industrial Engineering and Engineering Management (IEEM), Bali, pp. 238242.

Freivalds A. 2012. Niebel's Methods, Standard, and Work Design, $12^{\text {th }}$ Edition, USA: Mc Graw Hill.

Megbo, et al. 2015. Applications of Full Time Equivalent and Its Implications on Resources Planning in Nigerian Universities. Vol B, No 1. 